\title{
Josephine Miles (1911-1985): Doing Digital Humanism with and without Machines
}

\author{
Mario Wimmer, University of Basel
}

tyle and Proportion was both published and discounted in 1967. Ten years of hard intellectual work by Josephine "Jo" Miles, a poet and professor of English literature at the University of California at Berkeley, was dismissed by the very press that had carefully produced a strikingly original and lavish 200-page book.

Miles's passion for poetry was augmented by a curious interest in reading at a "middledistance," a term rather ironically coined by Franco Moretti in $2000 .{ }^{1}$ Given the current interest in digital humanism, Miles can be furthermore considered one of the pioneers of digital humanities - given that she concluded what today would be called a digital humanities project seventeen year prior to the publication of the first volume of Roberto Busa's Index Thomasticus, which is considered the beginning of digital humanities. ${ }^{2}$ It is not entirely clear why the historiography of digital humanism has mostly overlooked Miles contribution to the field. Thus far, two articles have accounted for her work as early digital humanist. ${ }^{3}$

The practice of distant reading across text, looking at semantic structures rather than doing hermeneutics of authors' intentions, has a long history. The example of Miles's scholarship shows that the field of digital humanities grew out of a rather orthodox research practice that can be connected to the big humanities projects of the nineteenth century. ${ }^{4}$ Back then, the hope was to establish a canon of texts to shape different national traditions. Accordingly, humanists in the academies of Berlin, Cambridge, or Paris were busy collecting, collating, and editing texts. The industrious efforts and good

1. Franco Moretti, “Conjectures on World Literature," New Left Review (2000): 54-68, and Distant Reading (London: Verso, 2013).

2. Rachel Sagner Buurma and Laura Heffernan, "Search and Replace: Josephine Miles and the Origins of Distant Reading," Modernism/modernity 3, cycle 4, 2018, https://modernismmodernity.org /forums/posts/search-and.

3. Christopher Rovee, "Counting Wordsworth by the Bay: The Distance of Josephine Miles," European Romantic Review 28, no. 3 (2017): 405-12; Buurma and Heffernan, "Search and Replace."

4. Kasper Risbjerg Eskildsen, "Commentary: Scholarship as a Way of Life - Character and Virtue in the Age of Big Humanities," History of Humanities 1, no. 2 (2016): 387-97.

History of Humanities, Volume 4, Number 2. http://dx.doi.org/10.1086/704850

(c) 2019 by Society for the History of the Humanities. All rights reserved. 2379-3163/2019/0402-0018\$10.00 
practice of nineteenth-century textual criticism - from Jacques-Paul Migne's edition of the church fathers to the publications of the Monumenta Germaniae Historica or the Cambridge edition of Shakespeare - shaped those corpora that, a century later, would be digitized to be read with the aid of algorithms and not critical attitude.

What makes Josephine Miles a classic in humanities scholarship is not so much the application of computer-processing power for literary research but the method of distant reading she first developed during her graduate work in the 1930s. In this short introduction to her work, I will not speak to her many books of poetry or the three volumes of literary scholarship that grew out of her dissertation and others to follow. ${ }^{5}$ Instead, I shall focus on two of her projects: the concordance of John Dryden (16311799) and her 1967 book Style and Proportion, which, for reasons to be explained, exists only in few copies around the globe. During her graduate work at the University of California at Berkeley, she developed a highly productive and original approach of literary analysis with linguistic tools. Parallel to her studies, she wrote poetry herself. ${ }^{6}$ It was her true passion. This became the reason for a curious choice of subject for her dissertation topic - the poetry of William Wordsworth (1770-1850). His poetry was at the time considered out of fashion and therefore did not have a chance to be critically appraised. This was exactly why Miles wanted to work on his language of emotion. She did not like it. "I am really more interested in finding out what I don't like and trying to understand that." " Her dislike of Wordsworth's language allowed for analytical distance, which, in turn, was supposed "to support and invite intuition."

\section{PROBABLY THE FIRST DIGITAL HUMANITIES PROJECT}

When Miles's senior colleague Guy Montgomery (1886-1951) passed away, he left an unfinished project: the concordance to the poetical works of John Dryden. ${ }^{9}$ Since Miles had experience with counting words and a reputation as a meticulous philologist, the

5. Rovee calls it a "formidable trilogy"; the three works are Josephine Miles, Wordsworth and the Vocabulary of Emotion (Berkeley: University of California Press, 1942), Pathetic Fallacy in the Nineteenth Century: A Study of a Changing Relation between Object and Emotion (Berkeley: University of California Press, 1942), and Major Adjectives in English Poetry: From Wyatt to Auden (Berkeley: University of California Press, 1946).

6. Josephine Miles, Collected Poems, 1930-83 (Champaign: University of Illinois Press, 1999).

7. Josephine Miles and Ruth Teiser, Poetry, Teaching, and Scholarship: Oral History Transcript; And Related Material, 1977-1980 (Berkeley, CA: Regional Oral History Office, 1980).

8. Josephine Miles, Style and Proportion: The Language of Prose and Poetry (Boston: Brown \& Little, 1967).

9. Guy Montgomery and Lester A. Hubbard, Concordance to the Poetical Works of John Dryden (Berkeley: University of California Press, 1957). 
department chair approached her to take it on. When Miles agreed to see the concordance to its conclusion, it was in the the form of 240,000 alphabetized cards, based on the Cambridge Edition. After a year of hard work, Miles realized that the project was in bad shape. Montgomery and his assistant, it seems, had not found a proper method of collating to account for the accuracy of the alphabetization. After talking to the linguist Charles Douglas Chretien (1904-69) about the project, he suggested using a computer as they already did in making dictionaries for exotic languages. Miles was intrigued and "went up to Cory Lab and said, 'You've got the computers up here. Can I do anything about making these concordances?" " Her colleagues in the department of electrical engineering and computer science were excited to help even though they had never done this before and did not quite know how. However they found a way of dealing with the "difficulty of accurate checking by assistants unfamiliar with the material." ${ }^{10}$ Together they decided to use an IBM 704a "large-scale, high-speed electronic calculator,"11 basically as an "aid in checking."

At this point, however, quotations could not yet be processed by machines. Montogmery's cards were translated into machine readable punch cards ${ }^{13}$ for each word, poem symbol, and line number. "The resulting listing was corrected, and the cards were then sorted by machine into poem and line order, so that proof could be read in text-order. After correction and return to alphabetical order, the final listing was made, the columns pasted three to a page on specially ruled sheets, and the pages then delivered to the Press for photolithography." ${ }^{14}$ In the preface to the published concordance she gives a list of what today would be called stop-words, that is, terms excluded from the concordance because they are insignificant, too frequent, or exceptional. As a result the book lists 208,000 word occurrences, after excluding around 32,000-33,000 according to the stop-list. Those listed are quite frequent and occur in a range in use between 400 and 1,100 times apiece. According to this analysis, fifty-seven words are particularly characteristic for Dryden's language. In short, Miles directed, in the early 1950s, what might be one of the first digital humanities projects in history. In retrospect,

10. Miles and Teiser, Poetry, Teaching, and Scholarship.

11. IBM Corporation, IBM 704 Electronic Data-Processing Machine: Manual of Operation (New York: International Business Machines Corporation, 1955), 5; Charles Bashe, IBM's Early Computers: A Technical History (Cambridge, MA: MIT Press, 1985). For a long history of machine aided text processing, see Markus Krajewski, Paper Machines: About Cards \& Catalogs, 1548-1929 (Cambridge, MA: MIT Press, 2011).

12. Miles and Teiser, Poetry, Teaching, and Scholarship.

13. A punch card in early computing was used to contain digital data. It represents $0 / 1$ by the presence or absence of holes.

14. Josephine Miles, preface to Montgomery and Hubbard, Concordance to the Poetical Works of John Dryden. 
however, the result seemed disappointing to Miles: "Nobody uses it unless he absolutely has to find out something about Dryden."15 The concordance provides the precise location of a word using only the coordinates, say, poem $X$, line $Y$. It thus lacks the beauty of concordances once described by Miles but operates on the level of the word, not the sentence.

\section{STYLE AND PROPORTION}

Starting in the later 1950s Miles wanted to take her approach to a new level. For about a decade she was doing meticulous work on the poetry and prose of England and America from the sixteenth century to the 1940s. No less than 120 works were sampled and scrutinized according to their relative number of adjectives, nouns, verbs, and connectives. The outcome was "more comprehensive and ambitious,"16 as one of the reviewers put it, than any of her previous studies in which she had pioneered a novel quantitative approach of literary analysis beginning in the 1930s. When she had finished the manuscript and overcome the problems of producing the tables for print, the Bostonbased Little \& Brown acquired the work for publication. However, there was a change of staff at the press. Her editor left his position, and the new one did not like what he saw. He told her, "Miss Miles, this is what I would call a non-book."17 When the publishing house was taken over by a conglomerate, they circulated only a small number of copies and shredded the remaining as a basis for tax loss.

Indeed, what Style and Proportion offered was a methodologically intriguing analysis of the language of English poetry and prose from the seventeenth to the twentieth centuries. Among Miles's archive one can find word-counting notes tracking the lexical habits of no fewer than 400 authors. The language of the 200 cases in point in Style and Proportion were categorized into three types - "predicative," "connective-subordinative," and "adjectival" - based on the number of adjectives, nouns, verbs, and connectives. Each of these groups characterize a particular type of crafting sentences, since "the art of

15. Miles and Teiser, Poetry, Teaching, and Scholarship.

16. W. O. S. Sutherland Jr., "Book Review: Style and Proportion: The Language of Prose and Poetry," College Composition and Communication 19, no. 3 (1968): 236-38. Altogether I was able to identify five reviews of the book which seems to be a lot given that the press took it from the market right after its publication. The other reviews, all equally enthusiastic and full of appreciation for the novel character of Miles's work, are DeLois Flemons, “Book Review: Style and Proportion: The Language of Prose and Poetry," CLA Journal 14, no. 3 (1971): 360-61; Helmut Hatzfeld, "Book Review: Style and Proportion. The Language of Prose and Poetry," Style 1, no. 2 (1967): 159-62; William Hendricks, "Book Review: Style and Proportion: The Language of Prose and Poetry," Lanquage 44, no. 3 (1968): 669-84; Sutherland, "Book Review"; and Martyn Wakelin, "Book Review: Style and Proportion. The Language of Prose and Poetry," Review of English Studies 22, no. 86 (1971): 243-46.

17. Miles and Teiser, Poetry, Teaching, and Scholarship. 
The Crescent-moon, the Star of Love.

Glories of evening, as ye there are seen

With but a span of sky between--

Speak one of you, my doubts remove.

Which is the attendant Page and which the Queen? (346)

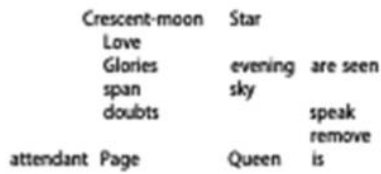

Figure 1. William Wordsworth, "Evening Voluntary” XI, February 1841 (left), Miles's analytical note, ca. 1930 (right); from Christopher Rovee, "Counting Wordsworth by the Bay: The Distance of Josephine Miles,” European Romantic Review 28, no. 3 (2017): 408.

sentence-making and figure-making in poetry and prose," as she put it, allows to account for particular styles, maybe even styles of thinking. The proportions of language she accounts for are the relations between those words that Miles had counted earlier.

Furthermore, Miles's analysis produced not just text but also visualizations of the proportions of language. The majority are tables; however, she also found a beautiful and intriguing way of representing the language of poetry, that recalls l'art concret, in particular concrete poetry and its elements of montage, linguistic awareness, and the use of language as acoustic and visual material. She arranged the semantics of major words counted in each poem according to the structure of the original (see fig. 1). Miles was ahead of her time not only in this respect-her avant-garde approach to literary analysis drew on various fields of research that, at the time, had not yet delivered the results that would have been necessary to bring her project to full success.

\section{FIRST PUBLICATION}

Miles, Josephine. 1967. Style and Proportion: The Language of Prose and Poetry. Boston: Brown \& Little.

\section{RECOMMENDED SELECTION FOR STUDENTS}

Miles, Josephine. 1967. Style and Proportion: The Language of Prose and Poetry, v-vii, 1-21, and 82-87. Boston: Brown \& Little.

\section{RECOMMENDED READINGS}

Josephine Miles Papers, The Bancroft Library, University of California, Berkeley (http://oac.cdlib.org /findaid/ark:/13030/kt0d5nc5z3)

Josephine Miles Papers, University Libraries, Special Collection, Washington University in St. Louis (http://digital.wustl.edu/w/wtu/wtuweb/wtu00084.xml.html)

Miles, Josephine. 1942. Wordsworth and the Vocabulary of Emotion. Berkeley: University of California Press.

1999. Collected Poems, 1930-83. Champaign: University of Illinois Press.

Miles, Josephine, and Ruth Teiser. 1980. Poetry, Teaching, and Scholarship: Oral History Transcript; And Related Material, 1977-1980. Berkeley, CA: Regional Oral History Office.

Montgomery, Guy, and Lester A. Hubbard. 1957. Concordance to the Poetical Works of John Dryden. Assisted By Mary Jackman and Helen S. Agoa. Preface By Josephine Miles. Berkeley: University of California Press. 
Moretti, Franco. 2000. “Conjectures on World Literature.” New Left Review, 54-68.

Rovee, Christopher. 2017. “Counting Wordsworth by the Bay: The Distance of Josephine Miles.” European Romantic Review 28 (3): 405-12.

Sagner Buurma, Rachel, and Laura Heffernan. 2018. "Search and Replace: Josephine Miles and the Origins of Distant Reading." Modernism/modernity 3, cycle 4. https://modernismmodernity.org/forums /posts/search-and. 